\title{
A NEW BUTTERFLY FOR SASKATCHEWAN AND MANITOBA
}

RONALD R. HOOPER, Saskatchewan Museum of Natural History, 2340 Albert St Regina, Saskatchewan. S4P 3V7

On 16 July 1988 Ken Pivnick of the Agriculture Research Station in Saskatoon was collecting insects near Val Marie on an insect survey of the proposed National Grasslands Park. He collected the first confirmed record of the Common Sooty Wing [Pholisora catullus (Fab.)] for Saskatchewan. On 17 July 1989 he collected one more in the same area which he donated to the Saskatchewan Museum of Natural History in Regina.

The Common Sooty Wing is a skipper with blackish-brown wings on both the upperside and the underside. It is easily recognized by a submarginal S-shaped row of 5 small white sports on each forewing. It differs from the Roadside Skipper by lacking checkered edges.

The larvae feed on pigweeds (plants of the genera Chenopodium and Amaranthus).

On 7 August 1989 Steve Lucyk of Balcarres, Saskatchewan collected one specimen of Common Sooty Wing Cromer, Manitoba along a grassy $r$ side. This species was previously repo for Manitoba, but when P. Klassen, Westwood, W.B. Preston and W.B. Killop wrote The butterflies of Mani (1989) they were unable to locate Manitoba specimens in any collecti This specimen, therefore, confirms species for Manitoba. It was donate the Saskatchewan Museum of $\mathrm{Na}$ History in Regina.

The Common Sooty Wing oc throughout most of the United $S$ north to Quebec, Ontario and $\mathrm{Br}$ Columbia. There are not yet any firmed records for Alberta (Nor Kondla: pers. comm.) although it reported for all three prairie provina W.W. Gregory in Checklist of butte and skippers of Canada.

This now brings the list of katchewan skippers (Hesperiidae) $t$ species. 